\title{
15. Reporting on Human Development: Lies, Damned Lies and Statistics ${ }^{1}$
}

\author{
Ian Castles
}

Popular opinion is mistaken in attributing the bon mot about 'lies, damned lies and statistics' to the American humorist Mark Twain, and Twain himself was probably mistaken in attributing the jest to the British statesman Benjamin Disraeli. In fact, the lasting slur upon statistics and statisticians was first brought to public notice in 1892, by one of the leading statisticians of the day.

As a senior public servant, Robert Giffen, head of the statistical department in the British Board of Trade, would have thought it improper to use the word 'damned' in a public address. But he introduced his paper on 'International Statistical Comparisons', presented to the first meeting of the Australasian Association for the Advancement of Science (AAAS) in Hobart, with the following sentences:

An old jest runs to the effect that there are three degrees of comparison among liars. There are liars, there are outrageous liars and there are scientific experts. This has lately been adapted to throw dirt upon statistics. There are lies, there are outrageous lies, and there are statistics. Statisticians can afford to laugh at ... jests at their expense... The statistics ... are not lies in themselves: it is only in the handling of them that the lying takes place. ${ }^{2}$

\section{Measuring human development: The Australian contribution}

In the late twentieth century the word 'damned' has become harmless, but 'lying' has become too strong a word for what most people see as a peccadillo: the misuse of statistics without any deliberate intent to deceive. So the title of today's Symposium offers us a softer alternative: there are facts, there are statistical estimates and there are fancies.

\footnotetext{
1 Originally published in Academy of the Social Sciences in Australia Annual Symposium 1999. Except where otherwise indicated, all figures and tables in this chapter are Castles' own.

2 Giffen, Robert (1892). 'International Statistical Comparisons' in Australasian Association for the Advancement of Science, Report of the Fourth Meeting, Hobart: 463.
} 
This title also pays tribute to the late Dr (later Sir) Roland Wilson, who as Commonwealth Statistician of Australia presented the celebrated paper 'Facts and Fancies of Productivity' to a meeting of ANZAAS, the successor body to the AAAS, in Adelaide in 1946. And the theme of today's meeting provides us with the opportunity to remember the extraordinary contribution that Australian scholars have made during the past century to the measurement of economic progress and to the knowledge of the conditions required for its achievement.

As many in today's audience know, the world's first official estimates of national income were produced by Timothy Coghlan, Government Statistician of New South Wales, in the 1890s; and the first comprehensive comparisons of the relative real incomes of different countries were produced by Colin Clark, a former Fellow of this Academy, in the late 1930s.

Roland Wilson's contribution has not been adequately recognised. His paper on the measurement of productivity was a masterly survey of the 'pitfalls in the way of those who seek to chart the course of material progress in mere figures'. Emphasising that 'well-being' was wider than 'economic welfare', and the latter concept 'comprehends more than the market-valued wealth which is the refuge of some economists but the only stock-in-trade of the economic statistician', Wilson went on to explore the reasons for 'the gradual divergence of wellbeing from productivity':

Another example ... is the growing tendency for work to become play, and thus to fall outside the statistician's measurement of productivity. With greater leisure more 'non-economic' work is done at home, such as household repairs, gardening and simple manufacture. Moreover, it is probably true that larger numbers of people spend longer hours in unpaid activity for charitable and social betterment purposes ... ${ }^{3}$

Another major Australian contributor to the recognition of the richness and variety of 'human development' was Wilson's predecessor Charles Wickens. In his paper 'Human Capital', presented to the ANZAAS conference in Wellington in 1923, Wickens recalled Oliver Goldsmith's reference to the 'hastening ills' which befall lands 'where wealth accumulates and men decay'. He questioned 'whether, as a matter of fact, the net result of such a process would not be a diminution of wealth in the proper sense', and asserted that there could 'be no worse policy in any community than that under which the health of the citizens is sacrificed to the increase of material goods'. According to Wickens' estimates, the value of Australia's 'human capital' was about 'three times the whole of the material capital, both private and public' ${ }^{4}$

3 Wilson, Roland (1947). Facts and Fancies of Productivity, Melbourne: 19.

4 Wickens, Charles H (1924). 'Human Capital' in Report of the AAAS (Wellington): 536-554. 


\section{The dangers of international statistical comparisons: Robert Giffen, 1892}

In his address to the AAAS in 1892, Robert Giffen argued that 'knowledge of the condition and growth of communities in the mass' was 'unattainable except by statistics'. But he wished to bring to attention 'the principal dangers in the handling of statistics to which the inexpert, and some of us perhaps who think we are expert, are exposed, through the too ready comparison with each other of figures which apparently are applied to facts of a like kind, but which really cover dissimilar facts'. With the 'extensive development of statistical abstracts, hand-books, year-books, manuals, dictionaries, statistical atlases and such like works of reference', there was a special need to be alert to these dangers in the field of international statistical comparisons:

Accustomed to see quantities, which are really dissimilar in kind, placed together under the same heading, which is done primarily for the mere purpose of reference, we come to neglect the dissimilarity in our speech, and, by and by, in thought... The numbers of ... production, imports and exports, and money wages in different communities are compared as if they in all cases meant the same things, and without any preliminary discussion of what the figures really do mean. All this is essentially mischievous, and is contrary to the most elementary lessons in the study of statistics. It is the part of the student to re-act against the temptation to which he is exposed to use works which are only good for reference in this haphazard fashion. ${ }^{5}$

Giffen supported his argument with a wealth of examples. He showed that comparisons of school populations in different countries often failed to take into account the differences in length of the school year; comparisons of crime rates ignored differences in the efficiency of police services; comparisons of wage levels glossed over differences in the occupational mix of the labour force and in the 'purchasing power of money in different places'; and comparisons of aggregate wealth needed to be 'accompanied by statistics of relative income ... and the like information'. All such comparisons were therefore vulnerable to the 'short cuts of the amateur partisan':

All the leading branches of statistics without exception ... give numerous illustrations of the dangers of taking ... figures ... from dictionaries or works of reference at haphazard for international comparison... [T] he figures as such may be right enough ... but [their] exact meaning ... may require a great deal of elucidation... There are ... many errors 
[in circulation] respecting the conditions of most communities, partly derived from and partly nursed by, the rash use of statistics with a more or less conscious bias towards a desired conclusion. ${ }^{6}$

At the end of the twentieth century, our statistical measures of wellbeing and of human development are far more advanced than they were a century ago, but it is a moot point whether there has been a corresponding advance in society's understanding of itself. To an extent that Giffen would have regarded as unimaginable a century ago, packaged information has displaced scholarship as the source of knowledge about the world in which we live.

\section{Monitoring human development: The eclipse of the social sciences}

It was easy for Robert Giffen to include himself among those 'who think we are expert'. He was the leading official statistician in the world's leading trading nation, at the zenith of British power and influence. Within weeks of his return from Australia, he was elected a Fellow of the Royal Society of London.

In the same year, one of Britain's leading academic statisticians, Karl Pearson, published The Grammar of Science, a classic work which made large claims for statisticians (including social statisticians) as scientists:

The field of science is unlimited... The unity of all science consists alone in its method, not in its material... The facts may belong to the past history of mankind, to the social statistics of our great cities, to the atmosphere of the most distant stars, to the digestive organs of a worm, or to the life of a scarcely visible bacillus. It is not the facts themselves which form science, but the method in which they are dealt with. ${ }^{7}$

In the 1990s, social statisticians can no longer 'afford to laugh at ... jests at their expense'. Robert Giffen turned out to be the last social scientist to be elected to the academy which in earlier years had welcomed: William Petty, author of the first estimates of national income; John Graunt, the first demographer; Robert Malthus, the pivotal figure in the history of population studies; and Stanley Jevons, the 'first economist effectively to introduce index-numbers of prices into Monetary Science'. ${ }^{8}$

6 Ibid: 486.

7 Castles, Ian (1998). 'The Methods of the Social Scientist', in Australian Research Council Challenges for the Social Sciences and Australia: 2. 295-6 (emphasis in original).

8 Keynes, JM (1930). A Treatise on Money: 1. 80. 


\section{The UNESCO/ICSU world conference on science: Budapest, June 1999}

The closing of ranks against social scientists by one of the world's oldest and most prestigious academies symbolises a strange paradox of the twentieth century. At its end we are told, rightly, that we live in an 'information society', and that the fostering of a 'knowledge economy' offers the only way forward for countries such as Australia whose present prosperity is supposed to have been built upon a wealth of natural rather than human resources. Yet there is less recognition than there was in Giffen's day that 'knowledge of the condition and growth of communities in the mass' is 'unattainable except by statistics'.

The place of the social sciences in UNESCO provides a case in point. Julian Huxley, the Organisation's foundation Director-General (and a Fellow of the Royal Society), declared in 1947 that 'Science in UNESCO's program ... must be taken to include all aspects of the pursuit and application of the organised knowledge of phenomena'. ${ }^{9}$

Social scientists might therefore have expected that UNESCO would lead the way in recognising the value of their disciplines: it is certainly not obvious that 'the social statistics of our great cities' are less worthy of scholarly attention than 'the digestive organs of a worm'.

But in the 1990s UNESCO gives scant recognition to the place of the social sciences in 'the pursuit and application of the organised knowledge of phenomena'. Earlier this year, its Director-General, Federico Mayor, gave the following explanation of UNESCO's decision to join with the International Council of Science (ICSU) to convene the World Conference on Science (WCS):

Science reigns triumphant. Never has it been so powerful and influential. It has conquered diseases which have decimated whole populations. It has abolished exhausting physical labour and wearisome repetitive tasks. It has vanquished distance and pushed back the frontiers of knowledge of the infinitely large and the infinitely small, in both the inanimate and the living world...

[But] ... humanity has the right to ask science to give priority into processes of global disruption and ways of coping with them. What's more, all citizens have the right to ask science to further our understanding of the mechanisms of inequality and exclusion which are gradually undermining peace and democracy... One major purpose of this meeting [the WCS] will be to see that the benefits of science

9 Huxley, Julian (1947). UNESCO: Its Purpose and its Philosophy: 34. 
go primarily to all those who have hitherto been unreached. Their conditions can only improve if they have access to the mighty power of science. ${ }^{10}$

There was no suggestion that there might be a place for political scientists, historians and economists in promoting 'our understanding of the mechanisms of inequality and exclusion', nor recognition that the establishment of the conditions of economic progress and human development might be a more complex matter than giving all citizens 'access to the mighty power of science'.

One of the preparatory documents for the WCS ('aimed at facilitating the understanding of the draft Agenda') assured prospective participants that 'Scientific research is increasing our knowledge and ability to understand complex systems and processes in an ever-wider range of scale in space and time'. But the UNESCO/ICSU Secretariat that prepared the document had a limited understanding of the complex systems and processes of human societies, as the following extract reveals:

Growing inequalities on all fronts ... today beset the world. The patterns of disparities are now more complex and contrasted. As one of many instances that illustrate the situation on a global scale, we recall that 20 per cent of humankind shares 86 per cent of the total private consumption. Within and between countries the benefits of education, culture, health services and other factors of human and social well being are ever more unequally distributed. ${ }^{11}$

At its final session, the Conference approved a Declaration proclaiming that global problems such as poverty, environmental degradation and inadequate public health were associated 'in particular ... with population growth', and urging 'Governments and scientists of the world [to] address ... the increasing inequalities in health across different countries'.$^{12}$ No empirical evidence was provided for these highly debatable propositions.

\section{The UNDP's Human Development Report}

There was, however, one statistical 'fancy' in the WCS documentation, reported as if it was a fact: ' $20 \%$ of humankind shares $86 \%$ of the total private consumption'. This statement was obviously based on the UNDP's Human Development Report 1998, which claimed that:

10 Mayor, Federico (1999). 'Science to what purpose?' The UNESCO Courier, May: 9.

11 World Conference on Science (1999a). Introductory Note to the Science Agenda - Framework for Action: 1.

12 World Conference on Science (1999b). Declaration on Science and the Use of Scientific Knowledge. (emphasis added). 
Globally, the $20 \%$ of the world's people in the highest-income countries account for $86 \%$ of total private consumption expenditures - the poorest $20 \%$ a miniscule $1.3 \% .^{13}$

In other words, private consumption per capita in the rich countries was 66 times greater than in the poorest countries. A chart on the opposite page of the report, headed 'Consumption is distributed inequitably', showed the 86 per cent allegedly shared by the 'richest $20 \%$ ' in green, the $12-13$ per cent shared by the 'middle $60 \%$ ' in white and the 1.3 per cent of the 'poorest $20 \%$ ' in black. ${ }^{14}$

The final chapter of last year's Report, headed 'Agenda for Action', asked rhetorically 'What would happen if the trends in consumption of the past 25 years were to continue for another 50 ? Where would that leave the world in the mid- $21^{\text {st }}$ century?' The answer, in part, was as follows:

The consumption of the fifth of the people in the world's poorest countries would still be well under $\$ 2000$ - not even 3\% of the rich country average at that time and under $10 \%$ of rich country levels today. ${ }^{15}$

The 'not even 3\%' figure tells us that in 50 years time, if the trends of the past 25 years continue, consumption of the fifth of the world in the rich countries would still be over 30 times greater than that of the fifth of the world in the poorest countries.

Yet on the back of its front cover, the 1998 Human Development Report tells its more vigilant readers that one of the stacks of blocks featured on the cover represents the ratio of the consumption levels of 'the $20 \%$ of people who live in the richest countries' to that of those of 'the $20 \%$ of people in the poorest countries'. This ratio is given as ' 16 times as much'. ${ }^{16}$

The difference between the ratio of 16:1 shown in the explanation of the 'stack of blocks' and the ratio of 66:1 given in the main text of last year's Human Development Report presumably arises because the former figure allows, and the latter figure does not allow, for differences in price levels between countries. The discrepancy is not a trivial one: yet the officials of the peak science bodies that prepared the documentation for the WCS, who reported as fact that the world is beset by 'growing inequalities on all fronts', were apparently unaware of its existence.

13 UNDP (1998). Human Development Report 1998: 2.

14 Ibid: 3.

15 Ibid: 86.

16 Ibid (emphasis added). 
The UNDP's Human Development Report 1999, which was released ten days after the WCS concluded its deliberations, repeated the claims about global inequalities which had attracted headlines in earlier years. Under the heading 'Stark disparities between rich and poor in global opportunity', a chart showed the 'Richest $20 \%$ ' had $86 \%$ of 'world GDP', the 'Middle $60 \%$ ' had 13 per cent and the 'Poorest 20\%' had one per cent of 'world GDP' ${ }^{17}$ As GDP was defined in the 'Definitions of statistical terms' as 'The total output of goods and services for final use produced by an economy ...', ${ }^{18}$ the Report gave the clear impression that the statistics quoted related to real output. In fact these percentages, like the similar figures relating to consumption expenditure in the 1998 Report, relate to the nominal value of production in national currencies, converted to a common currency (US dollars) on the basis of prevailing exchange rates.

These comparisons are spurious, as is apparent from the fact that in 1996 the UNCTAD secretariat, using data provided by the HDR Office itself, estimated that the proportion of the world's GDP produced by the richest quintile of the global population - ranking countries by their GDP per capita (PPP\$) - was 64.4 per cent in 1960 and 63.7 per cent in $1991 .^{19}$

The final chapter of the Human Development Report 1999 recalled the report of the Pearson Commission in 1969:

Nearly 30 years ago the Pearson Commission report began with the recognition that 'the widening gap between the developed and the developing countries has become the central problem of our times.' Today, global inequalities in income and living standards have reached grotesque proportions. The gap in per capita income (GNP) between the countries with the richest fifth of the world's people and those with the poorest fifth widened from 30 to 1 in 1960, to 60 to 1 in 1990, to 74 to 1 in $1995 .^{20}$

The emphasised words in this extract invite the conclusion that, over a 35-year period, per capita real expenditure on goods and services by the richest fifth of the world's people has more than doubled by comparison with that of the poorest fifth. Yet the figures from last year's report which have already been quoted imply that, if the trends of the past 25 years continue for the next 50 years, the corresponding ratio will be halved over the period. And the ratio of 74 to 1 between the top and bottom quintiles in the latest report does not sit easily with the ratio of 16 to 1 for 'overall consumption' cited on the back of the cover of last year's report.

17 UNDP (1999). Human Development Report 1999: 2.

18 Ibid: 254 (emphasis added).

19 UNCTAD (1996). The Least Developed Countries: 1996 Report: V.

20 UNDP (1999). Op cit: 104-05 (emphasis added). 
These massive contradictions arise from the mixed use, without explanation, of nominal (constant prices and constant exchange rates), nominal (current prices and current exchange rates) and real (international prices) data on output, income and expenditure in the statistics in the Human Development Report.

The contradictions are equally apparent in the confused presentation of data on energy use. For example, a table in the latest report ${ }^{21}$ presents, for each of over 120 countries, the 'Commercial energy use: GDP output per kilogram (US\$) 1996'. It is explained in a footnote that the ratios represent the 'Estimated real GDP (at 1987 prices) divided by kilograms of oil equivalent of commercial energy use'. No indication is given, either in the table or elsewhere, that 'real GDP (at 1987 prices)' in 1996 means 'nominal GDP in national currencies in 1996, revalued at the average prices in the specified country in 1987 and converted into \$US at the exchange rate which prevailed in 1987'. As the 'Definitions of statistical terms' in the report define 'GDP' as 'The total output of goods and services for final use produced by an economy', ${ }^{22}$ most readers would infer that the ratios are comparisons of energy use in relation to output - that is, of energy efficiency.

In fact, the Human Development Report Office itself is (or was) under the same impression. In the 1994 report it was claimed that the energy use was very inefficient in many developing countries:

There is tremendous scope for reducing energy input per unit of output.

For example, the energy consumed for every \$100 of GDP is 13 kilograms of oil equivalent in Japan, 18 in Germany, 35 in the United States, 50 in Canada and 254 in Romania. Energy use is even more inefficient in developing countries: as high as 187 kilograms of oil equivalent for every $\$ 100$ of GDP in China... ${ }^{23}$

The claim that more than five times as much energy is used per unit of GDP in China as in the United States is clearly erroneous. It may be compared with estimates by Angus Maddison. In The Chinese Economy in the Twentieth Century, under the heading 'The analytical relevance of PPP conversion', Maddison states that

My own estimates... suggest that China consumes... less [energy per unit of output] than... the United States... ${ }^{24}$

As in previous years, the claims in Human Development Report 1999 that global inequalities were rising and had reached 'bizarre proportions' received massive

\footnotetext{
21 Ibid: 201-204.

22 Ibid: 254 (emphasis added).

23 UNDP (1994). Human Development Report 1994: 18 (emphasis added).

24 Maddison, Angus (1998). Chinese Economic Performance in the Long Run. Paris: OECD: 154 (emphasis added).
} 
and uncritical coverage in the world's media. As well as publishing extended reports from their own correspondents at the Canberra launch, several Australian newspapers reproduced equally uncritical reviews from overseas. A London correspondent's report claiming that 'the gap between rich and poor widens inexorably' was reported in Melbourne under the heading 'The vacuum at the heart of the new world disorder' and in Canberra under the heading 'Putting morality into the globalisation equation'. Other headlines included 'Massive wealth divide exposed', 'Poverty gap grows wider', 'Globalisation brings further world injustice', 'Let's abandon the race to the bottom' and (from a Chicago correspondent) 'Rich getting richer as poor nations struggle on fringes of the global village' ${ }^{25}$

Succeeding sections of this paper will question the validity of the statistical evidence that underpins these claims of ever-widening inequality. This is not to doubt the existence of a wide gap in average living standards between rich and poor countries, nor to question that this gap widened in the early phases of modern economic growth. Most economic historians have recognised such a phenomenon, and have seen it as an ineluctable consequence of the fact that modern economic growth had to begin somewhere.

But it is fanciful to suppose that inter-country inequalities were still widening in the final decade of the millennium. The persistence of the myth in the face of massive statistical evidence to the contrary says much about the state of the social sciences in today's world.

\section{Colin Clark and the discovery of 'the gap"}

I have already referred to Colin Clark's pioneering comparisons of the relative real incomes of different countries, which were published in The Conditions of Economic Progress (1940). As Heinz Arndt has pointed out, this book, 'by supplying the first substantial evidence of the gulf in living standards between rich and poor countries, helped awaken Western opinion to the problems of underdevelopment ${ }^{\prime}{ }^{26}$ Writing in the late 1930s, Clark found the world to be

... a wretchedly poor place. ... Oft-repeated phrases about poverty in the midst of plenty, and the problems of production having already been solved if only we understood the problems of distribution, turn out to be the most untruthful of modern cliches. ${ }^{27}$

25 The Age (Melbourne) and The Canberra Times, 11 July 1999.

26 Arndt, HW (1990). 'Colin Clark as a Development Economist' in World Development, 18, 7: 1046.

27 Clark, Colin (1940). The Conditions of Economic Progress: 2-4. 
Angus Maddison, then aged 14, read the Australian economist's book in the public library near his home at Darlington, Durham. He was 'fascinated at the way [it] quantified what was going on in so many countries' and, in a memoir published in 1994, acknowledged its 'lasting effect' on his subsequent research agenda'. ${ }^{28}$ In the Kuznets Lectures at Yale University in 1998, Maddison paid tribute to Colin Clark's magnum opus:

At the time that [The Conditions of Economic Progress] appeared it was quite sensational in its breadth of perspective, and it demonstrated clearly the usefulness of a quantitative approach in clarifying the dimensions of economic performance and potential and the wide divergence between countries. ${ }^{29}$

With hindsight, it is easy to equate the gap that Clark identified with the 'north/south gap' which the Pearson Commission identified 30 years later as 'the central problem of our times'. But this is a simplistic view. Colin Clark's statistical snapshot did indeed show that there was a wide gulf between average incomes in the countries and those of poor countries in the inter-war years, but his painstaking assembly and analysis of the empirical evidence enabled him to explain this gulf within the context of a comprehensive theory of economic development.

Clark's recognition that 'the gap' was not immutable has been confirmed by the striking changes in relativities that have occurred in the six decades since the publication of his book. For example, the estimates which were of such interest to the young Angus Maddison showed average incomes in Brazil as higher than those in Italy; average incomes in Chile as higher than those in Japan; and average incomes in Argentina as higher than in all of these countries, and higher than in France, Germany, the Netherlands, Belgium and the Scandinavian countries.

In 1969, at the half-way point between the publication of The Conditions of Economic Progress and the present, the Pearson Commission still counted South Africa in 'the north', and Spain, Greece and Portugal in 'the south'. And, even now, the Population Division of the United Nations counts the Ukraine among the 'more developed regions' of the globe, and the Republic of Korea (with more than six times the average income of the Ukraine) among the 'less developed regions'. ${ }^{30}$

28 Maddison, Angus (1994). 'Confessions of a Chiffrephile' in BNL Quarterly Review, June: 435.

29 Maddison, Angus (1998). ‘Pioneers of Empirical Macromeasurement, 1665-1995' (The Twelfth Kuznets Lectures): 9.

30 World Bank (1969). Partners in Development: 358-359. 
Such a distinction could only be justified on historical or geographical criteria: Europe was, and for the most part still is, 'more developed' than Asia. But the consistent application of these criteria would require that Japan be included in the 'less developed regions'.

As well as significant changes between countries, the past two generations have seen dramatic changes in conditions within countries. Angus Maddison has told of his memories of the sickly and tubercular children of the unemployed in the north of England in the early 1930s, and of seeing 'nowhere so depressing [as Gateshead] ... until visiting Calcutta thirty years later'.$^{31}$ The poor of Britain are now less poor, but it would be a simplistic distortion of history to portray this change as 'the rich getting richer'.

\section{The conditions of economic progress: Colin Clark's views}

In The Conditions of Economic Progress, Colin Clark set out 'to give as much information as possible on the subject which after all concerns us most - namely to find the conditions under which we can hope for the greatest degree of economic progress in the future'.

Colin Clark's search for the conditions which could provide the greatest degree of economic progress in the future is easily open to the interpretation that he believed that societies should pursue the maximum possible growth in the output of material goods and services per head of population. Nothing could be further from the truth. Clark's view of the significance of 'economic growth' and of the role of the economist was well summarised in the following passage:

The desire for greater leisure will of course conflict with the desire to increase output of goods and services; and security for particular individuals and groups is often incompatible with maintaining a full rate of economic progress. On these two issues, and on other conflicts between purposes which may arise, it is not the business of the economist to make a decision. It is the business of the community as a whole in its collective or political capacity. It is the duty of the economist to inform the community, carefully and objectively, of the gains and losses which will follow each decision... If to all of these questions economics is to give a scientific and quantitative answer, its foundations must be firmly

31 Maddison, Angus (1994). Op cit: 435. 
built upon the ascertained facts of the production and distribution of goods and services. Only by the disciplined study of the facts of the present and the past can we make judgements upon the future. ${ }^{32}$

The following list of qualifications to the notion that economic progress can be measured as the output of goods and services per head of population are taken from the opening pages of the first edition of The Conditions of Economic Progress:

When ... we say that the average American enjoys greater economic welfare than the German, the German than the Italian, the Italian than the Indian, or present-day Europeans than their ancestors a century ago, we are perfectly well aware that the relative merits of these civilisations are not necessarily described by this economic ordering. A community making great economic progress may lack, and an economically unprogressive community may possess in full measure, the other values of life, such as a sense of contentment and of hope for the future...

Leisure is an element in economic welfare, and more precisely we can define economic progress as the attaining of an increasing output of ... goods and services [which are customarily exchanged for money] for a minimum expenditure of effort, and of other scarce resources, both natural and artificial...

A productive system leading to great inequalities of income between one person and another, or to great instability of income, even if it produces a higher output of goods and services, should be regarded as creating less economic welfare than a system from which these features are absent...

For certain countries ... the quoted figures of national income require to be reduced for the effects of wasting of natural assets in minerals and timber. This applies more strongly in the case of agriculture. No calculations have ever been made in any country as to the extent of exhaustion of natural fertility of soils and pastures... Though it is unfortunately as yet impossible to give even the most approximate numerical valuation of this destruction of natural resources in different parts of the world, the reader must carry in mind throughout very serious qualifications when examining all agricultural and pastoral statistics. $^{33}$ 
Clark went on to criticise the 'rather ignorant sophistication' of economists who 'say that it is impossible to compare the level of income between two communities or between two individuals, or even between the same individual at different times', and defended the view that 'economic welfare can be compared between times and places':

Purposive scientific generalisation differs from the meaningless accumulation of facts only in that the former uses the method of comparison. Comparisons of economic welfare between one community and another, one economic group and another, and between one time and another, are the very foundation of economic science. Anything which can be done to promote the scope and improve the technique of such comparisons is of fundamental importance. ${ }^{34}$

Despite Colin Clark's efforts to 'give as much information as possible' about 'the ascertained facts of the production and use of goods and services' and his explicit recognition that the world was 'a wretchedly poor place', his findings were not well understood except by some economists and statisticians. In an influential book published a quarter of a century later, with a foreword by Julian Huxley, a chapter entitled 'The cornucopian economists' explicitly nominated Colin Clark (as evidenced by his major book) among 'some economists and agronomists'

... who hold that the way to eliminate poverty in the world is to ignore population problems and concentrate solely on a more aggressive use of the earth and its materials, and that, given such use, there could be enough of everything to go around, no matter what numbers of people had to be supplied. It is necessary to discuss these men because, although their cornucopian theories do not seem to me to correspond to any observable facts of life in the vast, overpopulated, underdeveloped areas of the world, they are nevertheless sometimes eagerly hailed as economic optimists. ${ }^{35}$

\section{Human development and economic growth}

To the best of my knowledge, all recognised economists accept the substantial validity of Colin Clark's reasons for rejecting the notion that the maximisation of the marketable output of goods and services should be the chief end of human activity. Most economists in today's audience would therefore agree

34 Ibid: 26-27.

35 Appleman, Philip (1965). The Silent Explosion: 21, 141. 
with the proposition, which has been argued in successive issues of the Human Development Report since the series began in 1990, that there is 'a tension between wealth maximization and human development'.

They would, however, be surprised to find that the reports regularly portray economists (and, indeed, other social scientists and 'policy-makers') as being 'obsessed' with the former objective to the exclusion of the latter. Consider, for example, the following extract from the 1994 Report:

Only during the $20^{\text {th }}$ century did the social sciences become increasingly concerned with economics - and economics with wealth rather than with people, with the economy rather than with the society, with the maximization of income rather than with the expansion of opportunities for people. Although the obsession with materialism may be recent, the preoccupation of economists and policy-makers with augmenting 'national treasure', in surplus trade balances, dates back at least to the mercantilists, who preferred to concentrate on material success rather than with the development of human lives.

The dominant contemporary tradition of focusing exclusively on such variables as per capita gross national product or national wealth is a continuation - certainly an intensification - of the old opulenceoriented approach. And it is this low road of regarding humanity as an instrument of production - rather than the high road of acknowledging the universality of life claims - that fits well with the reputation of economics as a 'dismal science' ${ }^{36}$

In fact, of course, economics was dubbed the 'dismal science' not because its practitioners believed that humanity was merely an instrument of production, but for precisely the opposite reason. As I have pointed out elsewhere, the phrase had its origin in an 1849 article by the English historian Thomas Carlyle, who was prompted by reports of a strike by plantation workers in the West Indies to launch an attack on 'the dismal science' (emphasis in original) 'which ... reduces the duty of human governors to that of letting men alone'. Arguing that 'supply and demand' could not be 'the all-sufficient substitute for command and obedience among two-legged animals of the unfeathered class', Carlyle urged that 'pigs with pumpkins' be made to work 'with beneficent whip'. ${ }^{37}$

\footnotetext{
36 UNDP (1994). Op cit.

37 Carlyle, Thomas (1849). 'Occasional Discourse on the Negro Question', Fraser's Magazine, December [expanded version published separately as Occasional Discourse on the Nigger Question, 1853 and with the Latter-Day Pamphlets, 1858].
} 
Carlyle's unpleasant diatribe would not be worth recalling, but for the spirited response it evoked from the economist John Stuart Mill, who portrayed Carlyle as 'revolving in an eternal circle around the idea of work':

In opposition to the 'gospel of work', I would assert the gospel of leisure, and maintain that human beings cannot rise to the finer attributes of their nature compatibly with a life filled with labour... To reduce very greatly the quantity of work required to carry on existence is as needful as to distribute it more equally; and the progress of science, and the increasing ascendancy of justice and good sense, tend to this result. ${ }^{38}$

As I have shown, many twentieth-century economists have said much the same thing. The view that contemporary economists are obsessed with augmenting 'national treasure' reveals a fundamental misconception about the nature and purpose of economic studies.

\section{Inter-country and gender inequalities in health}

I have referred to the UNESCO/ICSU paper submitted to the WCS last June, which asserted that 'between countries, the benefits of ... health ... are ever more unequally distributed', and that 'the patterns of disparities [in general] are now more complex and contrasted'. I have also noted the Declaration subsequently endorsed by the conference that referred, inter alia, to 'increasing inequalities in health across different countries'.

If there is evidence to support these assertions, it might be expected that it would be found in the international comparisons of health status published annually in the WHO's excellent World Health Report. ${ }^{39}$ I have not been able to find such evidence in the tables in the latest report showing changes over time. The tables certainly support the statement that there are large inequalities in health, but not the generalisation that those differences are increasing. Almost without exception, they point to the contrary view.

The most universal and widely used measure of changes in health status over time and between countries is, of course, the average expectation of life at birth. Table 1 shows, for the 33 countries which had a population of over 30 million in 1997, the UN Population Division's estimates of the average expectation of life in 1952 and in 1997 (strictly speaking, for 1950-55 and 1995-2000). ${ }^{40}$

38 Mill, John Stuart (1850). 'The Negro Question', Fraser's Magazine, February (emphasis in original).

39 World Health Organization (1999). World Health Report.

40 United Nations 1998. World Population Prospects 1950-2050: The 1998 Revision. 
15. Reporting on Human Development: Lies, Damned Lies and Statistics

Table 1 Specified countries: Life expectancy at birth 1952-1997 (ranked by increase in life expectancy in years, 1952-1997)

\begin{tabular}{|c|c|c|c|c|c|}
\hline & \multirow{3}{*}{$\begin{array}{c}\begin{array}{c}\text { Population } \\
\text { Millions }\end{array} \\
1997 \\
\end{array}$} & \multirow{2}{*}{\multicolumn{2}{|c|}{$\begin{array}{l}\text { Life expectancy } \\
\text { Years }\end{array}$}} & \multicolumn{2}{|c|}{ Increase 1952-97 } \\
\hline & & & & \multirow{2}{*}{$\begin{array}{c}\text { Years } \\
1952-97\end{array}$} & \multirow{2}{*}{$\frac{\%(a)}{1952-97}$} \\
\hline & & 1952 & 1997 & & \\
\hline China & 1244 & 40.8 & 69.8 & 29.0 & 64.4 \\
\hline Indonesia & 203 & 37.5 & 65.1 & 27.6 & 61.3 \\
\hline Vietnam & 76 & 40.4 & 67.4 & 27.0 & 60.0 \\
\hline Turkey & 63 & 43.6 & 69.0 & 25.4 & 56.4 \\
\hline Pakistan & 144 & 38.9 & 64.0 & 25.1 & 55.8 \\
\hline Korea, Republic of & 46 & 47.5 & 72.4 & 24.9 & 55.3 \\
\hline India & 966 & 38.7 & 62.6 & 23.9 & 53.1 \\
\hline Egypt & 65 & 42.4 & 66.3 & 23.9 & 53.1 \\
\hline Myanmar & 44 & 36.9 & 60.1 & 23.2 & 51.6 \\
\hline Iran & 65 & 46.1 & 69.2 & 23.1 & 51.3 \\
\hline Thailand & 60 & 47.0 & 68.8 & 21.8 & 48.4 \\
\hline Mexico & 94 & 50.6 & 72.2 & 21.6 & 48.0 \\
\hline Bangladesh & 123 & 36.8 & 58.1 & 21.3 & 47.3 \\
\hline Philippines & 71 & 47.5 & 68.3 & 20.8 & 46.2 \\
\hline Colombia & 40 & 50.6 & 70.4 & 19.8 & 44.0 \\
\hline Japan & 126 & 63.9 & 80.0 & 16.1 & 35.8 \\
\hline Brazil & 164 & 51.0 & 66.8 & 15.8 & 35.1 \\
\hline Spain & 40 & 63.9 & 78.0 & 14.1 & 31.3 \\
\hline Nigeria & 104 & 38.5 & 50.1 & 13.6 & 30.2 \\
\hline Italy & 57 & 66.0 & 78.2 & 12.2 & 27.1 \\
\hline $\begin{array}{l}\text { Congo, Democratic } \\
\text { Republic of }\end{array}$ & 48 & 39.1 & 50.8 & 11.7 & 26.0 \\
\hline France & 58 & 66.5 & 78.1 & 11.6 & 25.8 \\
\hline Poland & 39 & 61.3 & 72.5 & 11.2 & 24.9 \\
\hline $\begin{array}{l}\text { Tanzania, United } \\
\text { Republic of }\end{array}$ & 31 & 37.0 & 47.9 & 10.9 & 24.2 \\
\hline Argentina & 36 & 62.5 & 72.9 & 10.4 & 23.1 \\
\hline Ethiopia & 58 & 32.9 & 43.3 & 10.4 & 23.1 \\
\hline Canada & 30 & 69.1 & 79.0 & 9.9 & 22.0 \\
\hline Germany & 82 & 67.5 & 77.2 & 9.7 & 21.6 \\
\hline South Africa & 39 & 45.0 & 54.7 & 9.7 & 21.6 \\
\hline United Kingdom & 58 & 69.2 & 77.2 & 8.0 & 17.8 \\
\hline United States & 272 & 69.0 & 76.7 & 7.7 & 17.1 \\
\hline Ukraine & 51 & 66.9 & 68.8 & 1.9 & 4.2 \\
\hline Russian Federation & 148 & 67.3 & 66.6 & -0.7 & -1.6 \\
\hline $\begin{array}{l}\text { Total: 'The World (b) of } \\
\text { which: }\end{array}$ & 4745 & 46.3 & 67.3 & 21.0 & 46.7 \\
\hline 'The South' (b) & 3784 & 41.1 & 65.3 & 24.2 & 53.9 \\
\hline 'The North' (b) & 961 & 67.0 & 75.4 & 8.4 & 18.6 \\
\hline $\begin{array}{l}\text { 'The North/South gap' } \\
\text { (b) }\end{array}$ & & 25.9 & 10.1 & -16.2 & -35.3 \\
\hline
\end{tabular}

(a) Increase in life expectancy as percentage of period over which increase was achieved (45 years).

(b) Population represents the total of the specified countries. The data represents the average of the specified countries in each region, weighted by their population in 1997. Thus the estimates for 'The World', 'The South' and 'The North' are, in effect, fixed-weighted indices relating to the specified countries in each of these regions.

Source: United Nations 1998. World Population Prospects 1950-2050: The 1998 Revision. 
The countries are ranked according to the absolute increase in life expectancy during the period. The data shown for 'The World', 'The South' and 'The North' represents the averages of the countries specified in the table (whose combined population amounts to more than 80 per cent of the global total), weighted by the populations of the countries in 1997.

The key points are that the weighted average life expectancy in the specified countries of 'The South' increased during the 45-year period by 24 years, compared with a weighted average increase of only eight years in 'The North'. As a result, the 'North/South gap' decreased from 26 years to 10 years, or by over 60 per cent.

The figures in the final column of the table are of particular interest. These show the increase in average life expectancy in each of the countries, expressed as a percentage of the period ( 45 years) over which the increase was achieved. In 10 countries, with a combined population amounting to more than half of the world total, this proportion exceeded 50 per cent for the entire 45-year period.

The declines in mortality that are reflected in these increases can only be described as extraordinary. In his paper 'World resources and world population', presented to the United Nations Scientific Conference on the Conservation and Utilization of Resources in 1949, Colin Clark noted as a phenomenon that

... in a mere 12 years, from 1923 to 1935, the Japanese expectation of life rose from 42.6 years to 48.3 years. ${ }^{41}$

Clark's example represented an increase in average life expectancy equivalent to 47.5 per cent of the period of 'a mere 12 years' over which it was achieved. It would have been unimaginable in 1949 that such a rate of increase could be maintained on average for half a century, in countries with a majority of the world's population.

Table 2 looks at the United Nations' estimates of life expectancy from a gender perspective. In this table, the 33 countries are ranked according to the excess of the average life expectancy of females over that of males.

41 Clark, Colin (1949). 'World Resources and World Population' in UNSCCUR Proceedings, 1: 15-27. 
Table 2 Specified countries: Life expectancy by gender 1952-1997 (ranked by excess of life expectancy of females over males in 1997)

\begin{tabular}{|c|c|c|c|c|c|}
\hline & \multirow{2}{*}{$\begin{array}{c}\begin{array}{c}\text { Population } \\
\text { Millions }\end{array} \\
1997\end{array}$} & \multicolumn{2}{|c|}{$\begin{array}{c}\text { Male } \\
\text { Total years }\end{array}$} & \multicolumn{2}{|c|}{$\begin{array}{c}\text { Female Excess over } \\
\text { male years }\end{array}$} \\
\hline & & 1952 & 1997 & 1952 & 1997 \\
\hline Russian Federation & 148 & 62.5 & 60.6 & 8.0 & 12.2 \\
\hline Ukraine & 51 & 63.3 & 63.8 & 6.3 & 9.9 \\
\hline Poland & 39 & 58.6 & 68.2 & 5.6 & 8.7 \\
\hline Brazil & 164 & 49.3 & 63.1 & 3.3 & 7.9 \\
\hline France & 58 & 63.7 & 74.2 & 5.8 & 7.8 \\
\hline Korea, Republic of & 46 & 46.0 & 68.8 & 3.0 & 7.2 \\
\hline Argentina & 36 & 60.4 & 69.7 & 4.7 & 7.1 \\
\hline Colombia & 40 & 49.0 & 67.3 & 3.3 & 7.0 \\
\hline Spain & 40 & 61.6 & 74.5 & 4.7 & 7.0 \\
\hline United States & 272 & 66.2 & 73.4 & 5.8 & 6.7 \\
\hline South Africa & 39 & 44.0 & 51.5 & 2.0 & 6.6 \\
\hline Germany & 82 & 65.3 & 73.9 & 4.3 & 6.3 \\
\hline Thailand & 60 & 45.0 & 65.8 & 4.1 & 6.2 \\
\hline Italy & 57 & 64.3 & 75.0 & 3.5 & 6.2 \\
\hline Japan & 126 & 62.1 & 76.8 & 3.8 & 6.1 \\
\hline Mexico & 94 & 48.9 & 69.5 & 3.6 & 6.0 \\
\hline Canada & 30 & 66.8 & 76.1 & 4.8 & 5.7 \\
\hline United Kingdom & 58 & 66.7 & 74.5 & 4.9 & 5.3 \\
\hline Turkey & 63 & 42.0 & 66.5 & 3.2 & 5.2 \\
\hline Viet Nam & 76 & 39.1 & 64.9 & 2.7 & 4.7 \\
\hline China & 1244 & 39.3 & 67.9 & 3.0 & 4.1 \\
\hline Indonesia & 203 & 36.9 & 63.3 & 1.2 & 3.7 \\
\hline Philippines & 71 & 46.0 & 66.5 & 3.1 & 3.7 \\
\hline Myanmar & 44 & 35.6 & 58.5 & 2.6 & 3.3 \\
\hline Egypt & 65 & 41.2 & 64.7 & 2.4 & 3.2 \\
\hline Congo, Dem Rep of & 48 & 37.5 & 49.2 & 3.1 & 3.1 \\
\hline Nigeria & 104 & 35.0 & 48.7 & 3.0 & 2.8 \\
\hline Tanzania, U Rep of & 31 & 35.6 & 46.8 & 1.0 & 2.3 \\
\hline Pakistan & 144 & 40.2 & 62.9 & -2.6 & 2.2 \\
\hline Ethiopia & 58 & 31.4 & 42.4 & 3.0 & 1.9 \\
\hline Iran & 65 & 46.1 & 68.5 & 0.0 & 1.5 \\
\hline India & 966 & 39.4 & 62.3 & -1.4 & 0.6 \\
\hline Bangladesh & 123 & 38.3 & 58.1 & -3.4 & 0.1 \\
\hline $\begin{array}{l}\text { Total: 'The World (a) of } \\
\text { which: }\end{array}$ & 4745 & 45.2 & 65.3 & 2.2 & 4.1 \\
\hline 'The South' (a) & 3784 & 40.4 & 63.8 & 1.3 & 3.2 \\
\hline 'The North' (a) & 961 & 64.2 & 71.5 & 5.5 & 7.7 \\
\hline $\begin{array}{l}\text { 'The North/South gap' } \\
\text { (a) }\end{array}$ & & 23.8 & 7.7 & 4.2 & 4.5 \\
\hline
\end{tabular}

(a) See footnote (b) to Table 1.

Source: United Nations 1998. World Population Prospects 1950-2050: The 1998 Revision.

A point of particular interest which emerges from Table 2 is that in 1997 the average life expectancy of males in 'The North' was 7.7 years greater than that 
of males in 'The South', but 7.7 years less than that of females in 'The North'. Since the early 1950s, the 'North/South gap' had narrowed by 16 years and the 'gender gap' had widened by two years.

\section{Inter-country and gender inequalities in education}

In exploring the claim by the UNESCO/ICSU Secretariat for the WCS that the benefits of health 'are ever more unequally distributed' between countries, we are faced with an immediate dilemma. The countries of 'The North' had already achieved universal primary education and universal adult literacy before estimates of primary school enrolment rates and of literacy among adults were available for many countries of 'The South'. There will therefore be a contraction, by definition, in the 'North/South gap' revealed in these human development indicators.

We need also to note that, if the statement by the UNESCO/ICSU Secretariat is true, the empirical supporting evidence should be available from UNESCO itself. The organisation is, upon its own testimony, 'the leading source of statistical information on education systems around the world', and 'the only universal organization entitled, by virtue of its Constitution, to ask Member States to provide it, on a systematic basis, with statistical data in all its fields of competence' ${ }^{42}$

To the best of my knowledge, none of the available empirical evidence lends support to the generalisation that there is ever-increasing inequality in the provision of the benefits of education - though it is true, as Gavin Jones points out, that the record in some regions has been disappointing. ${ }^{43}$ Some relevant information is presented in Table 3, which compares the combined gross enrolment ratios (GERs) for first-, second- and third-levels of education for 1970 and 1997, in respect of all of the countries with a population of over 30 million in 1997 for which UNESCO publishes comparable data for 1970 and 1997.

42 UNESCO (1997). Draft Program and Budget 1998-1999: 109.

43 See Gavin Jones' paper in Academy of the Social Sciences in Australia Annual Symposium 1999. 
Table 3 Specified countries: Combined gross enrolment ratios 1970-1997 (ranked by percentage increase in combined gross enrolment ratios)

\begin{tabular}{|c|c|c|c|c|c|}
\hline & \multirow{2}{*}{$\begin{array}{l}\text { Population } \\
\text { millions }\end{array}$} & \multicolumn{2}{|c|}{ Combined GER } & \multicolumn{2}{|c|}{ Increase 1952-97 } \\
\hline & & $\%$ & $\%$ & points & $\%(a)$ \\
\hline & 1997 & 1970 & 1997 & $1970-97$ & $1970-97$ \\
\hline Ethiopia & 58 & 7 & 24 & 17 & 343 \\
\hline Nigeria & 104 & 20 & 54 & 34 & 270 \\
\hline Pakistan & 144 & 19 & 43 & 24 & 226 \\
\hline Tanzania, U Rep of & 31 & 17 & 33 & 16 & 194 \\
\hline South Africa & 39 & 50 & 93 & 43 & 186 \\
\hline Egypt & 65 & 39 & 72 & 33 & 185 \\
\hline Brazil & 164 & 49 & 80 & 31 & 163 \\
\hline Indonesia & 203 & 40 & 64 & 24 & 160 \\
\hline China & 1244 & 44 & 69 & 25 & 157 \\
\hline Colombia & 40 & 47 & 71 & 24 & 151 \\
\hline Korea, Republic of & 46 & 61 & 90 & 29 & 148 \\
\hline India & 966 & 38 & 55 & 17 & 145 \\
\hline Spain & 40 & 66 & 92 & 26 & 139 \\
\hline Myanmar & 44 & 40 & 55 & 15 & 138 \\
\hline France & 58 & 70 & 92 & 22 & 131 \\
\hline Italy & 57 & 63 & 82 & 19 & 130 \\
\hline Thailand & 60 & 46 & 59 & 13 & 128 \\
\hline Argentina & 36 & 62 & 79 & 17 & 127 \\
\hline Mexico & 94 & 55 & 70 & 15 & 127 \\
\hline Japan & 126 & 67 & 85 & 18 & 127 \\
\hline United States & 272 & 75 & 94 & 19 & 125 \\
\hline Canada & 30 & 79 & 99 & 20 & 125 \\
\hline Bangladesh & 123 & 28 & 35 & 7 & 125 \\
\hline Philippines & 71 & 66 & 82 & 16 & 124 \\
\hline Turkey & 63 & 50 & 61 & 11 & 122 \\
\hline Congo, Dem Rep of & 48 & 43 & 39 & -4 & 91 \\
\hline $\begin{array}{l}\text { Total: 'The World' (b) } \\
\text { of which: }\end{array}$ & 4226 & 45 & 66 & 21 & 147 \\
\hline 'The South' (b) & 3643 & 41 & 62 & 21 & 153 \\
\hline 'The North' (b) & 583 & 71 & 91 & 20 & 128 \\
\hline $\begin{array}{l}\text { 'The North/South } \\
\text { gap' (b) }\end{array}$ & & 30 & 29 & -1 & -25 \\
\hline
\end{tabular}

(a) Combined gross enrolment ratio (GER) for 1997 expressed as index (GER for $1970=100$ ).

(b) See footnote (b) to Table 1.

Source: UNESCO (1999). Statistical Yearbook 1999. 
In this table, the countries are ranked according to the percentage increase in their combined GER over the 27-year period. The GERs for the specified countries in 'The South', weighted by their respective populations, increased by 53 per cent over this period, whereas the GERs for the specified countries in 'The North' increased by 28 per cent. Even if the comparison is made in terms of the rise in the number of percentage points, the increase in 'The South' was fractionally greater than in 'The North'. Among individual countries, the largest increases in terms of percentage points were in South Africa (43 percentage points), Nigeria (34 points), Egypt (33 points) and Brazil (31 points).

Table 4 presents the GERs for females for each of the countries over the 27-year period. The increase in the GERs for females in the specified countries of 'The South' exceeded 70 per cent over this period, compared with an increase of 33 per cent in the specified countries of 'The North'. The system of ranking of the countries in this table has been prompted by observations made by our Cunningham Lecturer, Professor Jack Caldwell, in his address at the National Club earlier this year:

... the degree of convergence in the education of the sexes in much of the world is remarkable. In great swathes of Asia and Latin America the extent of secondary schooling for girls is much above what it was in the West in the 1950s. Schooling ... implies subsequent full-time employment. In every country in the world where the majority of girls have at least three years' secondary education, the majority of women work and fertility is at replacement level or below. ${ }^{44}$

In the light of these comments, the ranking of countries in Table 4 is according to GERs in 'The South' in 1997 and in 'The North' in 1970. This form of presentation brings out the fact that, in 1997, the combined GERs for females in South Africa, the Philippines, the Republic of Korea, Argentina and Brazil were higher than the corresponding ratio for any of the specified countries in 'The North' in 1970.

44 Caldwell, JC (1999). 'Population...Explosion or Implosion?' Address at theNational Press Club, Canberra, 17 March 1999. 
Table 4 Specified countries: Combined gross enrolment ratios - females 1970-1997 (ranked by gross enrolment ratios in 'The South' in 1997 and in 'The North' in 1970)

\begin{tabular}{|c|c|c|c|c|}
\hline \multirow{3}{*}{ 'The South' } & \multirow{3}{*}{ 'The North' } & \multirow{2}{*}{$\begin{array}{c}\text { Population } \\
\text { millions }\end{array}$} & \multicolumn{2}{|c|}{ Combined GERs: Female } \\
\hline & & & $\%$ & $\%$ \\
\hline & & 1997 & 1970 & 1997 \\
\hline South Africa & & 39 & 53 & 94 \\
\hline Philippines & & 71 & 66 & 85 \\
\hline Korea, Republic of & & 46 & 57 & 84 \\
\hline Argentina & & 36 & 63 & 82 \\
\hline \multirow[t]{3}{*}{ Brazil } & & 164 & 48 & 77 \\
\hline & Canada & 30 & 76 & 102 \\
\hline & United States & 272 & 73 & 97 \\
\hline \multirow[t]{2}{*}{ Colombia } & & 40 & 47 & 71 \\
\hline & France & 58 & 70 & 94 \\
\hline Mexico & & 94 & 51 & 69 \\
\hline China & & 1244 & 39 & 67 \\
\hline \multirow[t]{3}{*}{ Egypt } & & 65 & 29 & 66 \\
\hline & Japan & 126 & 64 & 83 \\
\hline & Spain & 40 & 62 & 94 \\
\hline Indonesia & & 203 & 35 & 61 \\
\hline \multirow[t]{2}{*}{ Thailand } & & 60 & 43 & 59 \\
\hline & Italy & 57 & 59 & 83 \\
\hline Myanmar & & 44 & 36 & 54 \\
\hline Turkey & & 63 & 39 & 54 \\
\hline Nigeria & & 104 & 15 & 48 \\
\hline India & & 966 & 27 & 47 \\
\hline Tanzania & & 31 & 13 & 32 \\
\hline Bangladesh & & 123 & 17 & 31 \\
\hline Congo, D Rep of & & 48 & 9 & 31 \\
\hline Pakistan & & 144 & 30 & 28 \\
\hline Ethiopia & & 58 & 4 & 18 \\
\hline \multicolumn{2}{|c|}{ Total: 'The World' (a) of which: } & 4226 & 39 & 62 \\
\hline \multicolumn{2}{|l|}{ 'The South' (a) } & 3643 & 34 & 58 \\
\hline \multicolumn{2}{|l|}{ 'The North' (a) } & 583 & 69 & 92 \\
\hline \multicolumn{2}{|c|}{ 'The North/South gap (a) } & & 35 & 34 \\
\hline
\end{tabular}

(a) See footnote (b) to Table 1.

Source: UNESCO (1999). Statistical Yearbook 1999. 


\section{Inter-country inequalities in real income}

Inter-country inequalities in real income, or GDP per capita, have received more attention in the 1990s than inequalities in other 'factors of human and social well-being'. An important reason for this has been the introduction and growing influence of the UNDP's Human Development Report, which was launched in 1990. According to Amartya Sen, speaking at a memorial meeting for the originator of the series, Mahbub ul Haq, on 15 October 1998, this Report has 'had a profound effect on the way policy makers, public servants and the news media as well as economists and other social scientists view social and economic advancement' ${ }^{45}$

Ironically, the Report appears to have had the opposite effect to that intended by its founders. Their purpose was to focus attention on a more comprehensive concept of human development than GDP per head, and the human development index (HDI) was devised as a measure of such a concept. In practice, however, the main interest of the media has not been in the HDI, but in the sections of the Report and the accompanying publicity which purport to show that there has been a rapid and unprecedented widening in global income disparities.

Unlike the estimates of global income distribution made by Colin Clark in 1940 and those presented to us by Angus Maddison this morning, the estimates used in the text of the Human Development Report, and emphasised in the promotional material for the Report are not 'firmly built upon the ascertained facts of the production and distribution of goods and services'. In failing to take into account the large and varying differences in price levels between countries, they fail to provide the scientific and quantitative 'comparisons of economic welfare between one community and another, one economic group and another, and between one time and another' which Clark held to be 'the very foundation of economic science'.

Table 5 provides 'scientific and quantitative' comparisons of GDP per head in 1960, 1990 and 1997, for all of the countries with a 1997 population of over 30 million in respect of which such data can be calculated in 1997 PPP\$ from tables in the Human Development Report 1999 (for 1990 and 1997) and Human Development Report 1998 (for 1960). It also shows, for each country, annual growth rates over the long-term (1960-97) and in the 1990s (1990-97). Countries are ranked by their growth rates in the 1990-97-period.

45 Sen, Amartya (1998). 'Mahbub ul Haq: The courage and creativity of his ideas', speech at the Memorial Meeting for Mahbub ul Haq, 15 October. UNDP website. 
15. Reporting on Human Development: Lies, Damned Lies and Statistics

Table 5 Specified countries: Gross domestic product per capita 1960, 1990, 1997 (ranked by percentage per annum increase in GDP per capita 1990-1997)

\begin{tabular}{|c|c|c|c|c|c|c|}
\hline & \multirow{3}{*}{$\begin{array}{c}\begin{array}{c}\text { Population } \\
\text { millions }\end{array} \\
1997\end{array}$} & \multicolumn{5}{|c|}{ GDP per capita } \\
\hline & & \multicolumn{3}{|c|}{1997 PPP \$int. (a) } & \multicolumn{2}{|c|}{$\%$ per annum } \\
\hline & & 1960 & 1990 & 1997 & $1960-97$ & $1990-97$ \\
\hline China & 1244 & 416 & 1582 & 3130 & 5.5 & 9.7 \\
\hline Korea, Republic of & 46 & 1131 & 8963 & 13590 & 6.7 & 5.9 \\
\hline Indonesia & 203 & 845 & 2387 & 3490 & 3.8 & 5.4 \\
\hline Thailand & 60 & 1073 & 4619 & 6690 & 4.9 & 5.3 \\
\hline India (b) & 966 & 711 & 1290 & 1670 & 2.4 & 3.9 \\
\hline Argentina & 36 & 6919 & 8069 & 10300 & 1.1 & 3.5 \\
\hline Bangladesh & 123 & 703 & 862 & 1050 & 1.1 & 2.8 \\
\hline Colombia (b) & 40 & 3246 & 5908 & 6810 & 2.1 & 2.0 \\
\hline Pakistan & 144 & 505 & 1362 & 1580 & 3.1 & 1.9 \\
\hline Egypt & 65 & 712 & 2704 & 3050 & 3.9 & 1.7 \\
\hline Turkey & 63 & 2465 & 5879 & 6350 & 2.5 & 1.6 \\
\hline Spain & 40 & 4697 & 14314 & 15930 & 3.3 & 1.5 \\
\hline United States & 272 & 14419 & 26466 & 29010 & 1.9 & 1.3 \\
\hline Japan & 126 & 4516 & 22001 & 24070 & 4.5 & 1.3 \\
\hline United Kingdom & 58 & 9993 & 18970 & 20730 & 2.0 & 1.3 \\
\hline Brazil & 164 & 2531 & 5991 & 6480 & 2.5 & 1.1 \\
\hline Mexico (b) & 94 & 3902 & 7792 & 8370 & 2.1 & 1.0 \\
\hline Italy & 57 & 6911 & 19046 & 20290 & 2.9 & 0.9 \\
\hline France & 58 & 8571 & 20761 & 22030 & 2.6 & 0.8 \\
\hline Philippines & 71 & 2257 & 3342 & 3520 & 1.2 & 0.7 \\
\hline Canada & 30 & 9678 & 21623 & 22480 & 2.2 & 0.6 \\
\hline Nigeria & 104 & 961 & 908 & 920 & -0.1 & 0.2 \\
\hline South Africa & 39 & 5712 & 7797 & 7380 & 0.7 & -0.8 \\
\hline Congo, D Rep of & 48 & 2613 & 1724 & 880 & -3.0 & -10.0 \\
\hline 'The World' (c) of which: & 4151 & 2425 & 5485 & 6561 & 2.7 & 2.6 \\
\hline 'The South' (c) & 3510 & 1032 & 2332 & 3237 & 3.1 & 4.8 \\
\hline 'The North' (c) & 641 & 10056 & 22749 & 24761 & 2.5 & 1.2 \\
\hline 'The North/South gap' (c) & & 9.7:1 & 9.8:1 & 7.6:1 & 0.6 & 3.6 \\
\hline \multicolumn{7}{|l|}{ Weighted by population: } \\
\hline 'The World' (c) of which: & 4151 & & & & 3.3 & 4.5 \\
\hline 'The South' (c) & 3510 & & & & 3.4 & 5.2 \\
\hline 'The North' (c) & 641 & & & & 2.7 & 1.2 \\
\hline 'The North/South gap' (c) & & & & & 0.7 & 4.0 \\
\hline
\end{tabular}

(a) 1997 data is as given in UNDP, Human Development Report 1999, Table 1: 134-37. The data for 1990 has been calculated using the growth in GDP per capita (1987 US\$) from 1990 to 1997, as given in UNDP, ibid Table 6: 151-54. The data for 1960 has been calculated by the same method, but using GDP per capita (1987 US\$) for 1960 as given in UNDP, Human Development Report 1998, Table 5: 140-43.

(b) GDP per capita (1987 US\$) data for 1996 in UNDP (1999) op cit has been updated to 1997 using the growth rates in GDP per capita in IMF World Economic Outlook: May 1999.

(c) See footnote (b) to Table 1 . 
The levels and growth rates of GDP per head are also shown for 'The World' (i.e. the weighted average of the specified countries, whose combined population exceeds 70 per cent of the global total), 'The South' and 'The North'. The weighted average growth rates for these regional aggregates are shown on two bases:

- using GDP weights (i.e. weights that take account of the level of GDP per head in each country as well as the country's population); and

- using population weights (i.e. weights that take account of the population of each country, but not of its GDP per head).

On the latter basis of comparison the growth rates for the regional aggregates do not depend on the absolute levels of GDP per head in different countries, and are therefore independent of whether the 'purchasing power parity' or the 'exchange rate' method has been used to establish those relative levels.

In commenting on Table 1, I described the increases in life expectancy in the developing world since the early 1950s as 'extraordinary', and supported this judgement by citing Japan's experience in the inter-war period, as reported in 1949 by Colin Clark. The increases since 1960 in GDP per head in the developing world shown in Table 5, which are broadly consistent with those given by Angus Maddison in Table 3 of his paper to this Symposium, can be seen to be equally extraordinary by placing them in the perspective of judgements made in December 1948 by another great development economist, Dr (now Sir) Hans Singer:

As a result of the preoccupation of economists with national data and national problems... there has been a general tendency to assume that there has been a rise in per capita incomes the world over during the last two generations and also that there has been some progress towards a more equal distribution of income. This optimism cannot be seriously sustained if we think in terms of world income... While it is true that in some of the individual countries incomes and even per capita incomes have been rising, though at very uneven rates, the average or median world income is almost certainly smaller now than it was in 1913.

The reason for this is that in the determination of average international incomes the underdeveloped countries, with their expanding populations, acquire a constantly increasing weight. The situation is perhaps best described as follows: a shrinking proportion of the world population has been rapidly raising its standard of living, while the living standard of an increasing majority of the world population has been rising much more slowly or has remained stationary. The improvement 
within the first group and the very slow improvement in the second group are, however, swamped by the shift in relative numbers from the first group to the second...

In terms of world income, the situation has probably deteriorated during the last three generations in respect to all three Pigovian criteria: average size, equality of distribution, and stability over time. If we define the 'average' world income as that of the median world citizen, the spectacular improvement which has occurred at one extreme and which has fascinated economists and other observers becomes irrelevant. Such considerations perhaps lean over backward in the direction of gloom, but they may be a useful corrective of the prevailing view of the situation. ${ }^{46}$

This must be regarded as a well-informed assessment at the time that it was made. With the benefit of the estimates of modern economic growth that Angus Maddison and others have developed in recent decades, it seems clear that Singer's judgement did indeed 'lean over backward in the direction of gloom'. But Maddison's estimates suggest that the average rate of growth in income per head in the developing countries between 1870 and 1950 (Singer's 'last three generations') was well below one per cent annually.

The average growth rate of three per cent per annum achieved over the entire period from 1960 to 1997 is therefore without precedent. Moreover, the fact that the rate was even higher on a population-weighted basis shows that the benefits of this growth were widely spread: in our own time, the situation has almost certainly improved with respect to the Pigovian criterion of equality of distribution.

In 'The North', the growth rate of per capita incomes contracted sharply in the 1990s, but in 'The South' there was a marked acceleration. The trend was interrupted in 1997 by the 'Asian crisis', but it is already clear that the check was only a temporary one. The last decade of the millennium was almost certainly the first decade in history in which the average real incomes of most countries in which most of the world's poor lived increased at an average rate of three per cent or more. The objective evidence provides no support for the prevailing belief that inter-country inequalities in real income have been widening during the past decade. 